\title{
Contesting and re-negotiating the national in French cities: examining policies of governance, Europeanisation and co-option in Marseille and Lyon
}

\author{
JOSEPH DOWNING
}

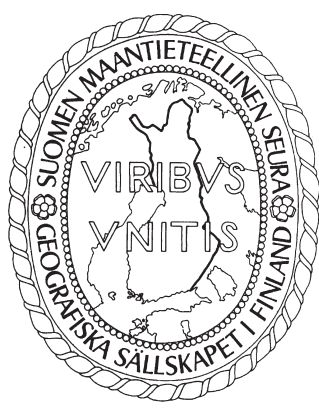

\begin{abstract}
Downing, Joseph (2015). Contesting and re-negotiating the national in French cities: examining policies of governance, Europeanisation and co-option in Marseille and Lyon. Fennia 193: 2, pp. 185-197. ISSN 1798-5617.
\end{abstract}

The past decade has seen a dynamic and contradictory treatment of difference in French policy-making, both nationally and locally. However, the means by which local difference orientated policies redefine the national is understudied. This article bridges this gap with a case study analysis of Marseille and Lyon to assess and typologize the ways that difference is deployed in local policy to influence, contest and negotiate the discursive performance and construction of the nation. Of particular importance here are modes of municipal governance, the influence of European government and the co-option of local voluntary groups into policy. This article concludes that both Marseille and Lyon provide rich examples of not only how municipalities are increasingly concerned with the notion of difference in policy-making, but also how their policies and engagement with local actors in dealing with nationally salient issues might lead to a redefinition of the national.

Keywords: France, diversity, migrants, national, local, state

Joseph Downing, European Institute, London School of Economics and Political Science, Houghton Street, London, WC2A 2AE, United Kingdom, E-mail: j.s.downing@lse.ac.uk

\section{Introduction}

The past decade has seen scholars identify an increasingly contradictory and negotiated process of formulating recognition-based policies in France that deploy notions of ethno-cultural and religious 'difference' (Bhabha 1994). This challenges the nationally ordained policy of assimilation, based around individual, formal, legal and political equality, in addition to the separation of church and state (laïcité), which has long worked as the guarantor of social integration and equality (Wihtol de Wenden 2003; Hargreaves 2007). The inability of this policy to resolve the socio-economic deprivation and discrimination experienced by communities from France's ex-colonies (Cesari et al. 2001; Hargreaves 2007) has indeed pushed policy makers to look for alternatives. The move away from assimilation towards difference-orien- tated policies has however taken place in a contradictory and contested manner, at both the national (Modood 2012; Dixon 2012) and local (Moore 2003; Doytcheva 2007; Raymond \& Modood 2007) scales.

This article seeks to add to this debate by shedding further light on the increasing use of such discursively constructed notions of difference at the local level (Moore 2003; Doytcheva 2007) and reflecting on their impact on the national ${ }^{1}$. In so doing, it assesses and typologizes how municipalities in Marseille and Lyon are deploying notions of difference in their policies, which end up challenging mainstream discourses of the national. To achieve this, the analysis conducted here begins with the idea that the local provides a medium through which shifting notions of national identities are articulated, negotiated and reproduced (Appleton 2002). Accordingly, as local municipali- 
ties deploy difference in various ways to address issues relevant to migrant communities, they indirectly influence how the national is articulated and constructed. This is not, however, to negate how discourses hostile to immigrants continue to inform the national public debate. Rather, this article aims to nuance the salience of these discourses in France by demonstrating how local policies and practices may also work to dovetail with, and reconfigure, them.

To this end, the article pursues a comparative analysis across three areas of policy activity in Marseille and Lyon. First, it will consider the relationship of the local French state to creating and deploying notions of difference in municipal governance and how these impinge on notions of French nationhood. Secondly, it will continue this analysis by examining the influence of European policy principles on the deployment of difference to contest or re-negotiate the national. Finally, it will look at the ways in which the local state is using notions of difference as a rationale dictating how it funds and co-opts local voluntary organisations and how this in turn resonates with a different understanding of the French nation.

\section{Nation, assimilation, and diversity in France}

Much has been written about assimilation rising to prominence in France (Brubaker 2001; Alba 2005; Bleich 2011). However, assimilation should not be seen as a unitary and static policy. While it has been venerated for successfully integrating France's diverse regions (Weber 1976) and multiple waves of immigrants from South and Eastern Europe (Weil 2008), this process has remained contradictory. It has never been a simple assimilation to a single, essential and unchanging notion of Frenchness, untouched by social and temporal developments. Rather, as Norial (1988) states, notions of Frenchness were remade by the very waves of immigration that the state sought to assimilate and resulted in new versions of Frenchness being forged (Swamy 2011).

Today the state continues, in a number of ways, to define the national in often contradictory terms, by deploying notions of difference in some measures, while maintaining assimilationist policies in other areas. Evidencing the application of principles of difference, Modood (2012) cites the crea- tion of the French Council of the Muslim Faith (CFCM, Conseil français du culte musulman) to represent Muslims in matters regulating worship and ritual and the creation of France's first national black association (CRAN, Conseil représentatif des associations noires de France) as important evidence of a possible shift towards multicultural policies in France. This, however, is not a completely novel development on the French scene, with a similar national Jewish association existing for over 50 years (CRIF, Conseil représentatif des institutions juives de France).

These developments also occurred in tandem with assimilationist measures, such as the 2007 introduction of French language tests for migrants (Contrat d'accueil et d'intégration) and the 2010 ban on the full face veil (Loi interdisant la dissimulation du visage dans l'espace public). Within this, it has long been argued from the latter half of the 20th century that the ability of assimilation to adequately integrate migrants from France's ex-colonies is extremely limited. This criticism stems in large part from the state's inability to resolve the severe socio-economic deprivation and xenophobic discrimination levelled at those immigrant communities from France's ex-colonies in the post-World War II epoch (Cesari et al. 2001; Hargreaves 2007). Thus, Hargreaves (2007) explains the participation in the 2005 riots of those from post-migration communities as a result of their alienation from the material and social benefits, owing to significant socio-economic disadvantage and racial and ethnic discrimination. This point is particularly important, because it connects the national and the local in an important way. The discrimination and marginalisation felt by those rioting in 2005 is a multifaceted process. At one level, this marginalisation is reproduced through national processes and discourses hostile to the place of migrants and their descendants in France. However, equal if not more important is the reproduction of this marginalisation locally, through a range of measures including direct employment discrimination, and sub-standard housing. In fact, as shall be demonstrated below, attempts to ameliorate social marginalisation in France have focused on the local contexts deemed such key dimensions in marginalisation's reproduction (Raymond \& Modood 2007).

Understanding the role of the local in this contradictory context is vital. This is because it has important implications for identifying and analysing how difference-orientated policies are de- 
ployed locally. The emergence of these policies does not occur in a vacuum, rather they are part of a broader process redefining and re-negotiating the relationship between difference and discursively formed notions of Frenchness. Within this relationship between notions of difference and the national, the local level has long been conceptualised as being notably dynamic in a number of ways (Raymond \& Modood 2007). The application of principles of difference in local policies is particularly notable for its plurality of forms across a plethora of locales. Moore's (2003) comparison of local policies of the management of difference in Manchester and Marseille highlights this trend. Here, Moore (2003) concludes that the French are moving towards a 'socio-cultural' model of multiculturalism, through the local authority's recognition of ethno-religious difference in the local policies. However, at the time of his research in the early 2000s, these policies remained covert and implicitly implemented without making a formal explicit statement that Marseille had decided to abandon assimilation and move towards a policy of recognition. This concurs with another broad observation in the literature that difference-orientated policies are frequently formulated and applied in France, without overt declarations. Doytcheva (2007) echoes this sentiment, by identifying the application of difference-orientated policies in the domain of an equality-driven model, where resources are funnelled to minority populations under the guise of urban renewal. Doytcheva's (2007) research in the Garges-Les-Gonesse and Vitry areas of Paris identifies a "French affirmative action" being practiced at the local level that singled out minorities for special funding, without making reference to such a policy goal.

This picture remains highly dynamic, with policy makers increasingly referencing the differenceorientated nature of their policies. One such example is the work by Marseille's ex-mayor, Jean Vigouroux, who attempted to reconcile the difference-orientated vision of the Marseille Espérance forum ${ }^{2}$, based on the notion of religious difference, with French secularism. For Vigouroux, his approach is an attempt at instituting a "secularism + religion" working framework (Vigouroux \& Ouaknin 2005). Here, bringing religion into the state is set as part of a tradition of "open secularism" (Vigouroux \& Ouaknin 2005) that does not contradict or jeopardise the neutrality (laïcité) of the central state. As such, the local and the national are locked into interplay where the national attempts to dictate policy principles locally, and the local replies with a negotiation of exactly how to interpret and apply these principles. As such, with important implications for this study, this example demonstrates how the national principles are moulded and applied locally. In other words, individuals will experience the nationally defining principle of laïcité at least partly through their application in the local context.

This experience of the local being a prism for the experience of the national is a well-established phenomenon in the literature where local processes are involved in not only representing, but also reproducing the nation (Appleton 2002; Confino \& Skaria 2002; Jones \& Fowler 2007). It is through the interplay between the local and the national that the nation as a discursive formation is reproduced (Jones \& Desforges 2003). As theorised in the literature (Billig 1995; Yoshino 1999; Brubaker et al. 2006), this discursive formation requires constant reproduction through performance, while also taking into account variations of interpretation by ordinary people as to a nation's meanings (Laitin 2007).

Thus, the local provides a medium through which shifting notions of national identities are articulated (Appleton 2002). Therefore, one should not take the local as being subsumed within the national, rather the local is transcended into higher levels of existence by becoming part of the national, as well as existing alongside it (Confino \& Skaria 2002). Bringing this discussion down to the empirical example of France, Confino and Skaria (2002) criticise Weber (1976), who asserted that the move from local peasants into Frenchmen was central to the making of the French nation. For them, instead, Weber (1976) mistakenly assumes that local identities are obliterated by the creation of the national. Rather, it is more accurate to assert that the local appropriates the national in such a way that the nation has various local meanings (Confino \& Skaria 2002). In summary, drawing on these arguments and applying them to the cases analysed here, it can be argued that at the local level, the spaces and places of local politics have an important effect in influencing the reproduction of the nation. This is even the case where local politics do not overtly seek to reproduce the nation, as Bodnar (1994: 16) argued: "Citizens view the larger entity of the nation through the lens of smaller units and places that they know first-hand".

This assertion of the local's importance in reshaping the national with the implementation of 
difference-orientated policies should not be taken, however, as an unproblematic endorsement of such difference-orientated policies. The observation that multiculturalism remains a multivalent and often contradictory, albeit important policy tool (Modood \& Uberoi 2013) rings as true today as ever. Any discussion of difference-orientated policies engages an enormous range of measures that are often reactionary, sometimes contradictory, owing to their ad-hoc evolution in response to temporal, social and economic changes (Modood 2007). However, under rising inequality imposed by the combined constraints of neo-liberal economic policies and post-2008 austerity, ensuring real economic equality for minority populations through multicultural policies is becoming an increasingly marginalized aim of such policies (Young 2009). Rather, socio-cultural models of multiculturalism have come to the fore (Young 2009), focusing on providing cultural and religious concessions to minorities and offering minorities 'recognition' of the validity of their cultures in the public realm, in a means analogous to Taylor's (1994) "politics of recognition".

The issues with this policy platform have been long debated, including but not limited to the allegations of post-colonial 'paternalism' (Littler \& Naidoo 2011), enshrining gender inequality (Phillips 2009) or abandoning overarching national identities (Modood 2012). Therefore, an a-historicised focus on the separation of minority cultures from unified mainstream that in some way should be preserved in its separateness and uniqueness has been correctly critiqued as divisive (Appingnanesi 2011) and cannot form the foundation of a viable socio-cultural model of multiculturalism. Both Appingnanesi (2011) and Littler and Naidoo (2011) assert that the issue of cultural diversity should not be handled as something that is either new, or something that will seep out into wider society in the future, but something that is part of the historical fact of cultures. This development of socio-cultural multiculturalism is important because, across Europe, the questions of race and ethnicity remain at the centre of debates about national heritage (Littler \& Naidoo 2011; Modood \& Uberoi 2013). Public culture, and the socio-cultural concessions possibly granted by multiculturalism remain important sites of cultural politics where power relations can be established, reproduced and importantly unsettled (Hall et al. 2013) by subverting and negotiating the hierarchies of symbolic and cultural power.

\section{Situating the case studies: Marseille and Lyon}

As France's second and third largest urban agglomerations, Marseille and Lyon, respectively, play an important role in redefining the national through the policy stances that they adopt. This is not to say that this redefinition is happening in similar ways. Rather, as can be expected, two separate cases will demonstrate varying degrees of commonality and difference in both socio-economic structures and policy trajectories. Lyon sits at the centre of one of the richest regions in Europe while Marseille is marked as a centre of urban precarity. Urban poverty in the Rhone department, of which Lyon is the capital, was $13.4 \%$ in 2011 compared to $17.8 \%$ in Bouches du Rhone, of which Marseille is the capital (INSEE 2011, cited in Hargreaves 2007). Marseille houses a "triangle of poverty", an area unparalleled in France for the proportion of the population living in poverty (Moore 2003). This very populous area is where the city's poor housing, unemployment and social problems are concentrated. Although Marseille is a much poorer city compared to Lyon, the latter has a higher level of income inequality; with significant poverty pockets concentrated in its suburban public housing estates, particularly to the south and east (Coudène 2010).

In both cities, poverty overlaps with ethnicity, as areas of deprivation in both Marseille and Lyon coincide with areas inhabited by people with migrant background, primarily from France's excolonies (Hargreaves 2007). The pitfalls of French ethnic minority statistics are well documented (Hargreaves 2007; Maxwell 2012), with the French census not collecting statistics on ethnicity or religion. However, researchers have challenged this state of affairs by making estimates. Hargreaves (2007), citing the INSEE statistics of foreign-born populations, indicates that $57.5 \%$ of these foreign-born reside in only three regions of France - île de France, with Paris at its centre, Rhône-Alpes, with Lyon at its core, and ProvenceAlpes-Côte d'Azur, with Marseille at its middle. Out of these, both Rhône-Alpes and ProvenceAlpes-Côte d'Azur have similar proportions of this population, at $11 \%$ and $10 \%$, respectively.

Policy wise, it is important to understand the historical situations of both cities that show significant differences. Marseille, as the main harbour of the French colonial empire, saw largescale migration earlier and in larger numbers 
than Lyon (Temine 1999; Gastaut 2003). After the independence of Algeria, over two million piedsnoirs ${ }^{3}$ entered France through Marseille, where many settled. This was alongside a well-established North-African population of economic migrants, whose numbers grew throughout the 20th century (Temine 1999). This led to early issues of discrimination and racism in Marseille that required the intervention of the municipal authorities to stop police violence against those of North African origin (Gastaut 1993). Lyon, however, saw inward migration from France's ex-colonies later, beginning in the middle of the 20th century with the arrival of North African migrant workers to fill industrial jobs in the greater Lyon region. Therefore, it is not surprising that Marseille and Lyon have been conceptualized as exhibiting distinct policy responses to the treatment of postmigration difference. Moore (2003) and Mitchell (2011) have asserted the unique nature of Marseille as an early adopter of multicultural policies, while Dikec (2007) and the Council of Europe (2008) have both identified Lyon as a case where the state has not engaged in the deployment of such policies. The differing governing structures existing in the two cases also complicates this picture. Marseille and its suburban concentrations of poverty are governed within the same urban municipality. Lyon, however, sits separately to its poor suburbs that exist in different communes, such as Vaulx-en-Velin and Vénissieux. While these are incorporated together in the Urban Community of Lyon (Communauté urbaine de Lyon, Grand Lyon) they retain considerable autonomy and separate planning and policy functions that have hampered efforts at greater incorporation of deprived suburbs into the Lyon urban area (Dikec 2007). However, this situation remains extremely dynamic, with Lyon being later identified as redefining the national by "taking a positive approach to interculturalism which is quite distinctive within the French context" (Wood 2010: 98), through its membership of the intercultural cities program.

In order to analyse the two examples of Lyon and Marseille, this article adopts a case study methodological approach. Here, it aims to sketch the key arguments about how municipal authorities in both cities are redefining the discursive nature of the national at the local level through the formulation and application of differenceorientated policies. Case studies are widely used in the social sciences. They serve a deductive purpose in their established use in research methodology as a means to highlight a more general theoretical point (Eckstein 1975). Case study methodology clearly has many shortcomings especially in terms of generalisation, where it is not possible to discriminate between theoretical causations from the single data point presented from one case study (Eckstein 1975). However, in a well-structured and logically reasoned deductive case study analysis important observations can be made about the nature of trends within a given situation (King et al. 1994). A case study research design suites the analysis conducted here. While the goal of research is often to make inferences that go beyond particular observations (King et al. 1994), and while this study has wider implications, generalisations will be kept to a minimum. To pursue the arguments within the key themes of this article, a deductive and theoretical approach will be adopted. This means that specific examples of the formulation and implementation of a redefinition of the national in difference-orientated policies will be selected as illustrations of the broader claims that policies formulated and applied in both cases demonstrates ways in which the discursive formation of the national is influenced at the local level. As such, the examples used are intended to paint a coherent yet incomplete account of process of the redefinition of the national at a particular place (Marseille and Lyon) and time.

The Author collected primary data through direct fieldwork in Marseille and Lyon, during $2011 / 2012$. A total of ten interviews were conducted with policy-makers and organizations based in the two cities. However, important issues exist with making direct interview quotations in France, where permission is required from the local state to directly attribute quotes to a civil servant. In addition, interviews were often not set up as interviews to be quoted directly because of the mentioned constraints. Rather, interviews were used as a means to guide this research through the exploration of real policy events and occurrences, which have been researched mainly through archival data. This included examining policy documents, the archives held by the organisations themselves (often available online) and newspaper reports about the particular activities of local actors. Importantly, these examples have been selected in line with the case study method criteria of choosing deductive examples that highlight a broader trend. It is from 
these deductive examples that the key arguments made in this article emerge. This approach is not intended, however, to ignore the broader, deep and persistent structural socio-economic problems in either Marseille or Lyon. Nor is the focus presented in this article a denial of the significant issues created for the redefinition of the national by media and political discourses in France that marginalise migrants and their descendants. Rather, the illustrative examples of the redefinition of the national discussed here serve to identify and analyse the various ways that principles of difference are deployed to challenge, negotiate and redefine the national.

\section{Redefining the national in the local: diversity and municipal governance in Marseille and Lyon}

As discussed above, the deployment of principles of difference remains contradictory and contested nationally. The local state, however, has been identified as more willing to deploy notions of difference in local policy (Raymond \& Modood 2007). As such, the local state and its modes of governance have played an important role in mediating how the discursively formed national can be redefined towards one that can include notions of difference. This is a critical observation for this study, in that the local prism through which individuals experience the national is being redefined in important ways. As such, it represents an important means by which the relationship between being French and notions of difference is being rewritten from the "bottom up" and demonstrates how the local does not exist independently of the national and vice-versa (Appleton 2002; Confino \& Skaria 2002; Jones \& Fowler 2007). As such, this local performance of the national contributes to the redefinition of the national context alongside, and in contestation with, measures from the central state hostile to difference, such as the headscarf ban (Simon 2005).

The ways in which Marseille and Lyon are deploying notions of difference that contribute more or less directly to redefine the national are multifarious. In Marseille, difference is primarily deployed in municipal governance as religious difference. This stems in part from local realities, where the municipality attempts to engage with an urban context that has seen both violent anti-
Jewish and anti-Muslim incidents (Gastaut 1993; Temine 1999). A civil servant interviewed for this research identified this communal violence as a starting point for thinking around policies that would enable the municipal authorities to engage directly with fighting racism and mediating disputes in the city. Initial attempts in this direction centred on identifying difference in an ethnic form to set up an inter-ethnic forum in the city. The civil servant interviewed stated that this resulted in too many groups being identified, somewhere in the hundreds, that would have made the forum unworkable.

It was at this point that it was decided to use religious difference as the foundation to create the forum in Marseille. Out of this context came the centrepiece of Marseille's urban governance strategy, the Marseille Espérance forum. The forum deploys religious difference to define membership based upon the city's seven largest religious communities - Muslim, Jewish, Catholic, Protestant, Armenian, Greek Orthodox, and Buddhist. This then brings the religious leaders of these communities together to undertake a number of municipal projects in the public domain. The public activities of the group are important in redefining the national for several reasons. The municipal authorities took the nascent principles of recognising religious difference used by the French state for some time, locally in Alsace-Lorraine $^{4}$, and nationally in creating a council for Jewish affairs (Conseil représentatif des institutions juives de France). Owing to colonial and post-colonial history, those of North African Muslim descent also suffered significant economic marginalisation and direct racial discrimination in the post-war period nationally (Gastaut 2003).

The municipality also gives the Marseille Espérance forum a high public profile by providing direct material support to the yearly Marseille Espérance intercultural gala event, where performances by various cultural community groups take place. This continues with the organisation of a "Marseille Espérance Jury" each year at the Marseille Documentary film festival, where they award the "Marseille Espérance Prize", endowed by the city of Marseille. However, its activities are not linked just to these symbolic events, as it also plays a more pronounced role in addressing local issues. Marseille Espérance's public endorsement of Marseille's grand mosque project demonstrates its concrete role in working on behalf of disadvantaged communities. The construction of this 
mosque can be read as an important step by the local state in reshaping the national so to incorporate ethno-religious difference. However, the importance placed on this development should not be overstretched, in that this event remains very much tied up in local considerations and occurs in a continued hostility towards Muslims in the French press.

Importantly, the use of difference as a policy principle is not a phenomenon limited to Marseille, but, in different ways, it is also at work in Lyon. Here, the explicit focus on difference deployed in Marseille is absent. Rather, difference is formulated in broader terms, also touching on notions of ethnicity that the French central state has been historically reluctant to engage with (Wihtol de Wenden 2003). The deployment of a broad definition of difference can be seen in the municipal authorities' ratification of the Charter of Diversity against discrimination in the workplace. This is a charter that seeks to fight discrimination in workplaces so to have workforces that "better reflect... the diversity of the French population" (Charte de la Diversité 2013: 1). Lyon was the first municipal authority in France to sign such a charter.

This is significant given the trend of French state institutions being reluctant to deploy notions of difference to promote the need to fight discrimination in the economic sphere. Previously, the central state has deemed a focus on individual equality before the law as being a sufficient guarantor of equality in the domain of employment (Withol de Wenden 2003; Hargreaves 2007). Now, as clearly evident in the case of Lyon, the French population is no longer treated as ethnically homogenous, but rather made up of a plurality of groups. Ethnically diverse citizens are subject to comparative disadvantages based on group membership and as such they require protection against discrimination. This explicitly difference-orientated approach designed to address endemic social issues through the recognition of group difference also applies to Lyon's creation of an "equality task force" to combat discrimination and promote equal opportunities, most importantly in housing and employment (Council of Europe 2012). This directly engages again with the questions of difference defined in both religious and ethnic terms, something that the central French state is yet to do.

These measures, while again not expressly identifying the national as their scale of activity, can be argued to be influencing the construction of the national at the local level through the performance of the discursive formation of the nation in that they cast ethnic and religious discrimination as inappropriate. As such, this public performance by the local state of a difference-orientated policy stance redefines how the legitimate conceptions of approaching the question of national identity are defined. As discussed under the promotion of equality in employment measures in the charter of diversity, the French population moves from being a homogenous national whole, to one that is constituted by both ethnic and religious difference. Again, however, this is happening in a broader context where such policies are yet to be implemented nationally, thus limiting the effect these measures have in redefining the national community as a whole.

\section{European influence on difference: redefining the national with Europeanisation in Marseille and Lyon}

The ability of the local to influence the discursive forms of the nation towards recognizing difference in both Marseille and Lyon is not limited to the activities of the local state in the domain of governance. Rather, this is also occurring through the application of European principles to cultural policy of both cities. Marseille and Lyon demonstrate a nascent, emergent trend within the French treatments of difference. Namely, the influence of European levels of government is being strongly felt in the aspects of both municipalities' cultural policies. This is important, because in both cities the cultural policies pursued by the municipal authorities are another important domain where the local French state is deploying difference in a number of ways. The character of the cultural production facilitated by the municipalities in both cases clearly points towards a redefinition of the nation as a discursive form towards one that accommodates various forms of difference. Importantly, this ability of municipal public culture to inform discursive formations in this way is not limited to the cases of Marseille and Lyon. Rather, there exists a literature addressing how municipal cultural policy has taken an active role in the redefinition of the national in, for instance, the UK, Canada and the US (Taylor 1994; Modood 2012; Littler \& Naidoo 2011). This is not to say that these activities have not been 
seen as problematic, as scholars have argued that they reinforce otherness and represent minority cultures as unitary entities with little room for heterogeneity (Littler \& Naidoo 2011). However, even their most adamant critics acknowledge that they are important means to redefine the national and challenge power hierarchies (Hall et al. 2013), providing they acknowledge the inherent diversity of both majority and minority cultures (Littler \& Naidoo 2011) and cast minorities in the positive positions of equality (Modood 2012). However, what has been under-researched is how European levels of government are impinging on how such notions of difference are deployed in municipal cultural policies. Both Marseille and Lyon represent important examples of how this trend is becoming increasingly important in France.

In Marseille, the influence of European governance is felt through the city's participation in the European Capital of Culture initiative in 2013. Here, the activities of the municipality in public culture have used difference in several forms. This represents an important example of how European principles are being applied to difference at the local level in France and it also results in an important contribution to the redefinition of the national. The use of cultural policies to inform the discursive reproduction of the national has in fact been central to the programme of Marseille's 2013 European Capital of Culture (MarseilleProvence 2013). In my interviews with civil servants working on Marseille-Provence 2013 (MP2013), they specifically identified as a focus of the programme the use of culture to represent and include all of the city's diverse residents. They placed significant importance on the role that MP2013 could play in challenging the negative conceptions of race and ethnicity not just in Marseille, but also in France more generally. This is important, because a key factor of the tendering process to hold the capital of culture title is to have a workable and viable means to express the difference present in potential candidate cities. Thus, in contesting for this European title, the municipality in Marseille was required to deploy difference in particular manners. The way this was operationalized was through recourse to the importance of the cultures of the Mediterranean region in contributing to the founding and growth of Marseille, from which the vast majority of Marseille's post-migration populations originate. As such, the notion of 'Mediterraneaness' in its application of difference could be argued to be a vector for a broader engagement with the contemporary cultural and ethnic difference present in Marseille. This theme runs through a number of flagship projects, for example, the Maison de la région, which was specially refitted in 2013 to include an interactive space to allow visitors to "discover the [Mediterranean] region" (Marseille-Provence 2013). Located in central Marseille in a prominent position on the city's best-known and busiest street, la Canebière, the Maison de la région commemorates the history and culture of the entire Mediterranean region. Inside there are posters, exhibitions and stone cladding on the walls showcasing all of the alphabets of the Mediterranean region, including Latin, Hebrew, Arabic, Armenian, and Phoenician. In addition, the Centre régional de la Méditerranée à Marseille (CRM), located on Marseille's docks, is another example of this process of recognizing difference in public culture through the 2013 program. Its mission statement is to be a "symbol of the exchange of knowledge and continuing dialogue between the cultures of the contemporary Mediterranean world" (Marseille-Provence 2013: 44). The centre acts as a forward thinking forum and marketplace where, at the same time "the commons roots of Mediterranean people are remembered" (Marseille-Provence 2013: 44). The above shows how the EU is indirectly influencing the treatment of difference in France towards its acceptance in the public realm.

This trend, again centred on the use of the idea of the Mediterranean as a vector for engaging with the city's difference, continues in the Museum of European and Mediterranean Civilisations (Musée des civilisations de l'Europe et de la Méditerranée - MuCEM), also opened in 2013. The museum is designed to commemorate the cultures and civilizations that have existed in the Mediterranean with a focus on their achievements. The museum hosts permanent collections from different Mediterranean civilizations as well as rotating exhibitions. One of the first of these exhibitions has been about different maps of the Mediterranean region from the 18th century onwards. The exhibition place Europe and France on par with North Africa and the Eastern Mediterranean and thus it implicitly recognizes that all these actors have contributed to the civilization of each other.

These large projects emanating from 2013 can be read as a clear attempt to re-tell the story of the national to take account of the contribution of regions and people from outside France. Importantly, in this case, these 'outsides' that have con- 
tributed to constituting France are places from where large proportions of post-migration populations have originated, thus opening up a space for them in the national narrative not simply to be assimilated, but as entities to be recognised for their contributions to France. As such, the reproduction and performance of the discursive form of the nation take on an interesting form here, where the contribution of those outside of the national frame adds to the national story.

This theme of European influence on the treatment of difference in cultural policy continues in Lyon through a different route. While in Marseille this influence has been exercised through the EU's European Capital of Culture initiative, in Lyon it has been through the Intercultural Cities Programme (ICP), co-produced by the EU and the Council of Europe. This is a program that specifically sets out to engage with challenging issues presented by difference in a way not present per se in the European Capital of Culture programme. The ICP seeks to facilitate member cities to combat discrimination and racism through the construction of meaningful dialogue between different cultural groups (Wood 2010). Central to Lyon's membership of the ICP has been the adoption of the citywide charter of cultural cooperation (Charte de coopération culturelle). While the charter was first drafted in 2004, it has been ratified during the 2012-2015 period. The attempt to redefine the national at the local level can be seen in a clause in the latest draft of the charter, ratified by all of the city's large, flagship cultural institutions, for the "valorisation of diversity, more visibility of minorities" and to promote "inter-culturality to introduce new arrivals [to Lyon]" (Ville de Lyon 2012: 1). This is a very important means to challenge the xenophobic constructions of the nation so prevalent in contemporary French discourse. By bringing minorities into the public displays of culture in the city directed by the local French state, the charter validates the place of these groups in society. This is a very important aspect of how theorists such as Taylor (1994) and Honneth (2007) have seen the provision of public recognition working. In addition, the anti-racism efforts widely documented in the USA and the UK demonstrate how the local level works as a very important vector in challenging national problems such as racism and discrimination (Modood 2007). Thus, given the fact that citizens also view the national through the prism of the local (Bodnar 1994), this could be said to be another measure by which, at least partially, the discursive form of the nation is being influenced.

However, membership of the ICP did not initially translate into difference-orientated policies in Lyon. Rather, Lyon has only actively undertaken this process much more recently. In 2008, Lyon was noted for a municipal cultural policy where diversity was still a 'non-issue' (Council of Europe 2008). This questionable start, however, has given way to significant dynamism. Lyon's municipal endorsement of deploying difference to redefine how minorities are included in broader discursive constructions of the national involves the co-option of local organisations working in closely related areas, among which is the Abrahamic group of la Duchère. Originating in the working class neighbourhood of la Duchère in 1986, the initial focus of the group was concerned with sharing spaces of worship and facilitating interreligious dialogue in La Duchère between Muslim, Jewish and Christian groups (Centre resource prospective du Grand Lyon 2012).

However, given the state's commitment to laïcité, which removes religion from public life, the local state did not become involved in these activities until its ICP membership. This points to the importance of the European level of governance in the ways difference is deployed locally. As such, the EU plays an important part in redefining how the national is performed locally, by facilitating the state's greater engagement with overtly religious groups locally. So far, this has resulted in the organisation, at the publically funded Musées Gadagne, of an exhibition about the religious minorities of Lyon. The event included discussions of the Armenian Christian, Jewish and Muslim presence in the city, with a session discussion of how "Lyonnais Islam" has been represented over the decades by community associations such as the Rhône-Alpes Council for the Muslim Faith (Musées Gadagne 2013). This is a significant step in redefining the national with the engagement of a key issue in the treatment of diversity in France. Speaking of a "Lyonnais Islam" redefines the national and local in important ways. It casts religion, importantly Islam, as something internal to the city at a time when the French media and political establishment have focused on Islam as external, alien and threatening to Republican values, through such political events as the banning of the headscarf in French schools in 2004. This incorporation of difference, 
however, should again not be over stated, given the remaining significant issues France is experiencing with discrimination against Muslim communities. Rather, it should be seen as an example of how the negotiation and contestation of the nation are very much still occurring, at multiple scales, and are far from settled.

\section{Redefining the national from below: cooperating with NGOs in Marseille and Lyon}

Another means by which the local state in Marseille and Lyon is offering recognition to difference is through the funding and cooperation agreements with local non-governmental organisations (NGOs). By influencing how difference is played out in local spaces, NGOs are taking part in redefining the discursive performance and re-production of the national. This is because they are using notions of religious and ethno-cultural difference to validate the place of those of migrants in society. Thus, this is in direct confrontation with the performance of the nation present in France, where discussions about ethnic and religious difference are depicted as incompatible with French society. This is specifically prevalent around the depictions of those of Muslim of North African origin, with measures such as the banning of praying in the streets in France (Vinocur 2011). This ban occurred after extensive media and political debate during which Marine Le Pen, the leader of the far-right National Front, declared praying in the street a form of occupation and invasion. As previously demonstrated, the exact implementation of this co-option of local NGOs and the implications this has for applications of difference principles varies between Marseille and Lyon.

For Marseille, NGOs such as the Union of Muslim Families of the Bouches-du-Rhône have received direct funding from the city municipal authorities for activities such as the "Eid in the city" festival. Given the considerable hostility towards religion in recent French legislation, particularly directed towards Islam, Marseille's stance as the only city in France that funds a public celebration of the Muslim holiday of Eid al Adha poses a significant challenge to the national mainstream. The "L'Aïd dans la Cité" (Eid in the city) festival is therefore a unique example of how a city is rewriting locally a sense of the national to publically validate and normalize a minority religion in the public realm (Pervis 2007). Eid in the city is considered to be a valuable opportunity to meet other members of the local community in a festive context, and it helps counter the more negative images of Muslims that tend to predominate and get the most attention (Open Society Foundations 2011). It is also important to note that this example of the redefinition of the national is not simply concerned with, and serving, the Muslim community, as the event specifically invites members of the non-Muslim community and regularly achieve $30 \%$ attendance by non-Muslims (Pervis 2007). The celebration of the festival takes a broader approach than a focus on religion, since it offers a vast range of activities so that a wide community and family audience can join in the festive atmosphere. Here, the use of public space and municipal funds to perform the validity of the place of Muslims in France is a powerful means by which national and local prejudice is countered, challenged and renegotiated.

This overt character of locally based measures offering the public recognition of diversity in France is also evident in the relationship between NGOs and the local state in Lyon. In this case, the means by which difference is addressed overlaps with, and varies from, measures deployed in Marseille. The religious overtones deployed in the support of Eid in the city in Marseille are absent while the actual substantive cultural content bears many similarities between the two cases. An example of this is the collaboration with the Rhône-Alps Centre of Traditional Music (Centre Des Musiques Traditionnelles Rhônes-Alpes, CMTRA). While working for several decades on "valorizing heritage and recognizing the cultural diversities of the territories of Rhône-Alps" (Centre Des Musiques Traditionelles Rhone-Alps 2012: 1), the CMTRA has only recently been co-opted by the Lyon's municipality to aid in their implementation of the ICP. The municipality has provided the CMTRA with a public space to hold "World Music Thursdays" (Ville de Lyon 2012). This can also be read as an effort to open up Lyon to music whose origin makes cultural diversity present in the public realm. Here, the CMTRA concentrates on bringing out in the public sphere music and cultural forms that may otherwise be confined into the private sphere of the family and religious services. To this end, among other projects, they generated a "sound atlas" of the 8th arrondissement (an ethnically diverse area of 
Lyon), which is available online (www.cmtra.org). It was accomplished over a two-year period by a team of researchers who lived in the area and who employed anthropological ethnographic methods to document the stories and daily lives and music of musicians living in the area, meeting them in their houses and taking pictures for online publication. In total this atlas showcases 13 acts from Africa, South America, the Arab world, and the Caribbean. This is another example of how work being done to recognise difference in Lyon is being co-opted and, therefore being given greater exposure, by the local state.

\section{Conclusion}

The varying ways in which difference is deployed in France to renegotiate and redefine the national remains an important issue for scholarship. As seen from the evidence presented here, the national remains in France a very dynamic subject. In identifying the flexibility of local politics to deal with questions of difference-orientated policies, this article has added to the earlier work of Raymond and Modood (2007). However, building on the work of Moore (2003) and Dyotecheva (2007), the article has also demonstrated that the formulation of difference-orientated policies are increasingly occurring in the public realm, with overt recourse being made to notions of difference in public policy.

More importantly for the analysis conducted here is how this increased attention to difference dovetails with redefining and contesting the national. Building on various scholarships (Bodnar 1994; Appleton 2002; Confino \& Skaria 2002; Jones \& Fowler 2007) that have demonstrated the importance of the local in defining the national, the article has also shown how the national is reproduced and performed in a plurality of discursive ways (Billig 1995; Yoshino 1999; Brubaker et al. 2006). The local is important in redefining the national both as a vector for the contestation of national grievances and also as the lived experience through which individuals encounter and make the national present. The analysis has also demonstrated the importance of local policy initiatives in tackling discourses of xenophobia and discrimination that remain nevertheless prevalent in how the French nation is reproduced.

However, one should remain cautious about the extent to which the measures discussed here have a general effect. These policy innovations remain in- deed situated in France within a context of heightened anti-immigrant, specifically anti-Muslim, rhetoric. This has significant implications for attempting to redefine the national locally, in a context where paradoxical and contradictory messages of exclusion have significant visibility. In addition, the enduring conditions of austerity in the French social policy context mean that it is unlikely that, in the medium term, the measures discussed here will be coupled with concerted efforts to reduce economic marginalisation in post-migration communities.

Nevertheless, with these limitations in mind, it is worth reflecting on how the examples discussed above reflect an important evolution in the ways in which the national might be redefined 'bottom-up'. Firstly, measures like Marseille Espérance and Lyon's commitment to fighting racial discrimination in its workforce demonstrate how local policies initiatives can address the issues of marginalisation faced by those of migrant origin in France. It is important to note that measures to tackle difference-related issues are also influenced by European government. Both Marseille and Lyon demonstrate how efforts to validate the place of minorities in society through European initiatives such as the European Capital of Culture or the ICP can be harnessed by policy makers to redefine the national via local activities. Finally, this analysis demonstrates how NGOs are being co-opted to further these processes of providing recognition to minorities in Marseille and Lyon. This is an important point, because as well as a national trend, the social and economic dimensions of discrimination and racism are indelibly local in their manifestation. Thus, by offering some elements of inclusion at the local level, inclusion in the national can be created by extension.

\section{NOTES}

${ }^{1}$ Echoing Antonsich and Matejskova (2015), I use the term 'national' to refer to both an identity discourse and a spatial register which intervenes in political, social or economic contexts.

2 The Marseille Espérance forum was instituted in 1990 by the then mayor Robert Vigouroux in response to a rise in anti-semitic activity that culminated in the desecration of the historic Jewish cemetery in Carpentras, 100 kilometres outside of Marseille, by far right extremists. It brings together the leaders of the city's largest religious communities to engage in an ongoing cross-cultural dialogue.

${ }^{3}$ Pieds noirs was the name given to European settlers who migrated to France in the aftermath of the independence of French North African colonies. 
${ }^{4}$ Alsace-Lorraine was part of the German Empire when the law of 1905 separated church and state in France. As such, the French state directly funds the four recognized religions enshrined in Concordat of 1801 in Alsace-Lorraine in variance to the rest of France.

\section{ACKNOWLEDGEMENTS}

I would like to thank Marco Antonsich for organising this special issue and also for his indispensable support in the preparation of this article.

\section{REFERENCES}

Alba R 2005. Bright vs. blurred boundaries: secondgeneration assimilation and exclusion in France, Germany, and the United States. Ethnic and Racial Studies 28: 1, 20-49.

http://dx.doi.org/10.1080/0141987042000280003.

Antonsich M \& Matejskova T 2015. Immigration societies and the question of 'the national'. Ethnicities 15: 5, 1-14.

Appingnanesi R 2011. Introduction: 'whose culture?' Exposing the myth of cultural diversity <http:// www.creativecase.org.uk/introduction-whoseculture> 12.07.2012.

Appleton L 2002. Distillations of something larger: the local scale and American national identity. Cultural Geographies 9: 4, 421-447.

Bhabha HK 1994. The location of culture. Routledge, London. Billig M 1995. Banal nationalism. Sage, London.

Bleich E 2011. Social research and 'race' policy framing in Britain and France. The British Journal of Politics \& International Relations 13: 1, 59-74. http://dx.doi.org/10.1111/j.1467-856X.2010.00439.x.

Bodnar J 1994. Remaking America: public memory, commemoration and patriotism in the twentieth century. Princeton University Press, Princeton.

Brubaker R 2001. The return of assimilation? Changing perspectives on immigration and its sequels in France, Germany, and the United States. Ethnic and Racial Studies 24: 4, 531-548.

http://dx.doi.org/10.1080/01419870120049770.

Brubaker R, Feischmidt M, Fox J \& Grancea L 2006. Nationalist politics and everyday ethnicity in a Transy/vanian town. Princeton University Press, Princeton.

Centre Des Musiques Traditionelles Rhone-Alps (CMTRA) 2012. <http://www.cmtra.org/> 12.07.2012.

Centre Resource Prospective du Grand Lyon (CRPL) 2012. Groupe Abraham de la Duchére <http:// www.millenaire3.com/Affichage-de-la-ressource. 122+M51a10fb25bd.0.html 12.07.2012.

Cesari J, Moreau A \& Schleyer-Lindenmann A 2001. PLUS MARSEILLAIS QUE MOI, TU MEURS! Migrations, identités et territoires à Marseille. Editions L'Hartmann, Paris.
Charte de la Diversité 2013. Charte de la Diversité: Une Initiative d'enterprises <http://www.chartediversite.com/charte-diversite-la-charte.php> 12.07.2012.

Confino A \& Skaria A 2002. The local life of nationhood. National Identities 4: 1, 7-24. http://dx.doi.org/10.1080/14608940120115657.

Coudène M 2010. Grand Lyon : la précarité reste concentrée à l'est de l'agglomération <http://insee.fr/fr/themes/document.asp?reg_id=8\&ref_ $i d=16691$ \#sommaire $>$ 21.07.2014.

Council of Europe 2008. Intercultural cities. Council of Europe, Strasbourg <www.coe.int/t/dg4/cultureheritage/culture/cities/Lyonprofile_en.pdf> 12.07.2012.

Council of Europe 2012. Projects and policies that help to make Lyon a lively cultural city. Council of Europe, Strasbourg. <http://www.coe.int/t/dg4/cultureheritage/culture/cities/lyonprojets_EN.asp> 17.08.2012.

Dikec M 2007. Badlands of the republic: Space, politics and urban policy. Blackwell, London.

Dixon C 2012. Decolonising the museum: Cité Nationale de I'Histoire de I'Immigration. Race \& Class $53: 4,78-86$.

http:/dx.doi.org/10.1177/1469605313501582.

Doytcheva M 2007. Une discrimination positive a la Française? Ethnicité et territoire dans les politiques de la ville. Broché, Paris.

Eckstein H 1975. Case study and theory in political science. In Greenstein F \& Polsby N (ed). Handbook of political science, 79-138. Addison-Wesley, Boston.

Gastaut Y 1993. La flambée raciste de 1973 en France. Revue européenne de migrations internationales 9: 2, 61-75. http://dx.doi.org/10.3406/remi.1993.1355.

Gastaut Y 2003. Marseille cosmopolite après les décolonisations: un enjeu identitaire. Cahiers de la Méditerranée 67, 269-285.

Hall S, Evans J \& Nixon S (ed). 2013. Representation: cultural representations and signifying practices. Sage, London.

Hargreaves A 2007. Multi-ethnic France: immigration, politics, culture, and society. Routledge, London.

Honneth A 2007. Disrespect: the mormative foundations of critical theory. Polity, London.

Jones R \& Desforges L 2003. Localities and the reproduction of Welsh nationalism. Political Geography $22: 3,271-292$ http:/dx.doi.org/10.1016/S0962-6298(02)00096-3.

Jones R \& Fowler C 2007. Placing and scaling the nation. Environment and Planning D: Society and Space 25:2, 332-354.

http:/dx.doi.org/10.1068/d68j.

King G, Verba S \& Keohane R 1994. Designing social inquiry: scientific inference in qualitative research. Princeton University Press, Princeton.

Laitin D 2007. Nations, states and violence. Oxford University Press, Oxford.

Littler J \& Naidoo R 2011. The politics of heritage: the legacies of 'race'. Routledge, London. 
Marseille-Provence 2013. Marseille 2013 European capital of culture programme. <http://www. mp2013.fr/ext/avp-en/> 01.07.2012.

Maxwell R 2012. Ethnic minority migrants in Britain and France. Cambridge University Press, Cambridge.

Mitchell K 2011. Marseille's not for burning: comparative networks of integration and exclusion in two French cities. Annals of the Association of American Geographers 101: 2, 404-423. http:/dx.doi.org/10.1080/00045608.2010.545290.

Modood T 2007. Multiculturalism: a civic idea. Polity Press, Cambridge.

Modood T 2012. Still not easy being British: struggles for a multicultural citizenship. Trentham books, Stoke on Trent.

ModoodT \& Uberoi V 2013. Inclusive Britishness: a multiculturalist advance. Political Studies 61: 1, 23-41. http:/ dx.doi.org/10.1111/j.1467-9248.2012.00979.x.

Moore D 2003. Ethnicité et politique de la ville en France et en Grande-Bretagne. Editions L'Harmattan, Paris.

Musées Gadagne 2013. Les minoritiés religieuses a Lyon de Moyen Age a nos jours. <http://www.gadagne. musees.lyon.fr/index.php/histoire_fr/Histoire/Programmation/Conferences-colloques/Histoire-de-Lyon/Histoire-des-eglises-a-Lyon> 27.04.2013.

Norial G 1988. Le creuset francais: histoire de l'immigration XIXe-XXe Siecles. Seuil, Paris.

Open Society Foundations 2011. Muslims in Marseille. Open Society Foundations, London.

Pervis A 2007. Marseille's ethnic bouillabaisse: some view Europe's most diverse city as a laboratory of the continent's future. <http://www.smithsonianmag. com/travel/marseille-200712.html> 12.07.2014.

Phillips A 2009. Multiculturalism without culture. Princeton University Press, USA.

Raymond G \& Modood T 2007. The construction of minority identities in France and Britain. Palgrave, London.
Simon P 2005. La république face à la diversité: comment décoloniser les imaginaires? In Bancel $\mathrm{N}$, Blanchard P \& Lemaire S (ed). La fracture colonial, 241-251. Poche, Paris.

Swamy V 2011. Interpreting the republic: marginalisation and belonging in contemporary French novels and films. Lexington Books, New York.

Taylor C 1994. The politics of recognition. In Guttman A (ed). Multi-culturalism and 'the politics of recognition', 25-73. Princeton University Press, Princeton.

Temime E (ed) 1999. Migrance: histoire des migrations a Marseille. Editions Jeanne Laffite, Paris.

Vinocur N 2011. France bans street prayer. <http:// www.reuters.com/article/2011/09/16/us-francemuslims-idUSTRE78F4CC20110916> 24.07.2014.

Weber E 1976. Peasants into Frenchmen: the modernization of rural France, 1870, 1914. Stanford University Press, Stanford.

Weil P 2008. How to be French: nationality in the making since 1789. Duke University Press, Durham.

Wihtol de Wenden 2003. Multiculturalism in France. International Journal on Multicultural Societies 5: 1, 77-88.

Wood P 2010. Intercultural cities: towards a model for intercultural integration. Council of Europe, Strasbourg.

Vigouroux R \& Ouaknin J 2005. Laicite + religions: Marseille espérance. Transbordeurs, Marseille.

Ville de Lyon 2012. Charte de coopération culturelle. <http://www.polville.lyon.fr/static/polville/contenu/ Culture/CHARTE\%20\%203.pdf> 27.04.2013.

Yoshino K 1999. Consuming ethnicity and nationalism: Asian experiences. Wiley, London.

Young I 2009. Structural injustice and the politics of difference. In Christiano T \& Christman J (ed). Contemporary debates in political philosophy, 362-383. Blackwell, Oxford. 